J. Clin. Chem. Clin. Biochem.

Vol. 23, 1985, pp. 337-342

\title{
Human Salivary Arginase and Its Deficiency in Argininaemia ${ }^{1}$ )
}

\author{
By L. Konarska, L. Tomaszewski
}

Department of Clinical Biochemistry, Medical School of Warsaw, Poland,

\section{J. P. Colombo}

Department of Clinical Chemistry, Inselspital, University of Berne, Switzerland and

\author{
H. G. Terheggen
}

Spezialarzt für Kinderheilkunde, Köln, Federal Republic of Germany

(Received December 3, 1984)

Summary: Arginase from normal human mixed saliva was characterized. The enzyme was completely activated after a preincubation of $20 \mathrm{~min}$ at $55^{\circ} \mathrm{C}$ and a $\mathrm{Mn}^{2+}$ final concentration of $5 \mathrm{mmol} / \mathrm{l}$. The $\mathrm{pH}$ optimum was $9.6-9.8$, and the $K_{\mathrm{m}}$ for $L$-arginine was $4.2 \pm 0.7 \mathrm{mmol} / 1$. In normal saliva only one form was found, which was chromatographically identical with the cationic form of arginase in liver and blood cells. Salivary arginase was completely precipitated by rabbit antiserum against human liver arginase.

Arginase activity was not detectable in the saliva of patients suffering from argininaemia. Enzyme activities in the saliva of the heterozygous parents and the unaffected daughter were $0.08,0.07$ and $0.12 \mathrm{U} / \mathrm{mg}$ protein, respectively, whereas the activities in the saliva of 60 healthy adults and 8 children were $0.17 \pm 0.11$ and $0.16 \pm 0.06 \mathrm{U} / \mathrm{mg}$ protein, respectively.

\section{Menschliche Speichel-Arginase und ihr Fehlen bei der Argininämie}

Zusammenfassung: Die aus gemischtem Speichel gewonnene Arginase wurde charakterisiert. Nach Präinkubation von $20 \mathrm{~min}$ bei $55^{\circ} \mathrm{C}$ und einer $\mathrm{Mn}^{2}-$ Endkonzentration von $5 \mathrm{mmol} / \mathrm{l}$ wird das Enzym voll aktiviert. Das pH-Optimum lag zwischen 9,6-9,8; der $K_{\mathrm{m}}$-Wert für Arginin betrug 4,2 $\pm 0,7 \mathrm{mmol} / \mathrm{l}$. Im normalen Speichel konnte nur eine Form der Arginase gefunden werden. Diese ist chromatographisch identisch mit der kationischen Form der Leber- und Erythrocytenarginase. Die Speichelarginase wird durch gegen menschliche Leberarginase gerichtetes Kaninchenserum vollständig präzipitierrt.

Im Speichel von Patienten mit Argininämie konnte keine Arginaseaktivität nachgewiesen werden. Die Enzymaktivität im Speichel der heterozygoten Eltern betrug 0,08 resp. 0,07, diejenige der gesunden Schwester $0,12 \mathrm{U} / \mathrm{mg}$ Protein. Im Speichel von 60 gesunden Erwachsenen fand sich eine Aktivität von $0,17 \pm 0,11$, bei 8 Kindern eine solche von $0,16 \pm 0,06 \mathrm{U} / \mathrm{mg}$ Protein.

\section{Introduction}

Argininaemia is an inborn metabolic disorder of the urea cycle due to arginase ( $L$-arginineamidinohydrolase, EC 3.5.3.1) deficiency. The enzyme deficiency has been demonstrated in liver (1),

\footnotetext{
1 Presented in part at the 3rd International Symposium on Inborn Errors in Humans, Munich 1984.
}

erythrocytes (2-4) and leukocytes (5). In this paper we report deficient arginase activity in the saliva of homozygous patients, together with our findings on the properties of arginase from normal human saliva. Kinetic, chromatographic and immunological similarities of salivary, hepatic and blood cell arginases suggest that they are genetically identical. 


\section{Materials and Methods}

\section{Sampling and preparation of saliva}

Saliva was sampled from 60 healthy adults, aged $18-65$ years, 8 healthy children, aged 1 to 4 years, and from three siblings with argininaemia (6), their heterozygous parents and healthy sister. Two individual samples at intervals of an hour were obtained from each patient. Specimens of mixed saliva were taken during unstimulated secretion following prior rinsing of the oral cavity. They were centrifuged at $1200 \mathrm{~g}$ for $5 \mathrm{~min}$ and the supernatant used for enzyme determinations.

Before the arginase assay, salivary mucus was dispersed by sonication at $0^{\circ} \mathrm{C}\left(2 \times 20 \mathrm{~s}, 40 \mathrm{~W}\right.$, Sonifier $\mathrm{B}_{12}$, Branson Sonic Power Company, USA) or emulsified by homogenization in a Teflonglass Potter type homogenizer for $1 \mathrm{~min}$ at $2000 \mathrm{~min}^{-1}$.

For chromatographic and immunological procedures, saliva was homogenized with 2-mercaptoethanol in a final concentration of $0.2 \mathrm{~mol} / \mathrm{l}$, and incubated at $0^{\circ} \mathrm{C}$ for 2 hours in order to lower mucus viscosity (7). Any precipitate was then removed by centrifugation and the supernatant was used for further investigation.

\section{Arginase assaj'}

Arginase activity was measured by the amount of ornithine liberated from $L$-arginine as substrate. Ornithine was determined by the method of Chinard (8).

For the arginase assay, saliva from healthy subjects was diluted 5 -fold. The reaction mixture $(0.5 \mathrm{ml})$ contained $0.5 \mu \mathrm{mol}$ of $\mathrm{MnCl}_{2}, 10 \mu \mathrm{mol}$ of arginine and $30 \mu \mathrm{mol}$ of carbonate buffer, all adjusted to $\mathrm{pH} 9.8$, and $0.05 \mathrm{ml}$ of enzyme preparation. After incubation at $37^{\circ} \mathrm{C}$ for $15 \mathrm{~min}$, the reaction was stopped with $1.5 \mathrm{ml}$ of concentrated acetic acid, then $0.5 \mathrm{ml}$ of ninhydrin solution was added $(2.5 \mathrm{~g}$ of ninhydrin in a mixture of $40 \mathrm{ml}$ of $6 \mathrm{~mol} / 1 \mathrm{H}_{3} \mathrm{PO}_{4}$ and $60 \mathrm{ml}$ of glacial acetic acid). After heating in.a boiling water bath for 1 hour the mixture was cooled and the absorbance was read at $515 \mathrm{~nm}$ against a reagent blank. A zero time blank was performed for each individual specimen of saliva.

To measure fully $\mathrm{Mn}^{2+}$-activated arginase, the mixtures containing $0.05 \mathrm{ml}$ of enzyme preparation and $0.05 \mathrm{ml}(0.5 \mu \mathrm{mol})$ of $\mathrm{MnCl}_{2}$ were preincubated at $55^{\circ} \mathrm{C}$ for $20 \mathrm{~min}$. After cooling, arginine and carbonate buffer were added, and the procedure was performed as described above. Arginase in erythrocytes was determined as described previously (9).

Arginase activity was expressed in units per $\mathrm{mg}$ of protein. One unit of arginase is defined as the amount of enzyme that produces $1 \mu \mathrm{mol}$ of ornithine per minute at $37^{\circ} \mathrm{C}$.

Protein was measured according to Lowry et al. (10) with cristalline bovine serum albumin as a standard.

\section{Ion-exchange chromatography}

For chromatography on DEAE- or CM-cellulose, saliva was homogenized and incubated with 2-mercaptoethanol and then dialysed overnight against $5 \mathrm{mmol} / 1 \mathrm{MnCl}_{2}$ in $5 \mathrm{mmol} / \mathrm{l}$ Tris$\mathrm{HCl}$ buffer, $\mathrm{pH} 8.3$ or 7.5 respectively. Any precipitate was removed by centrifugation and the supernatant was applied to the cellulose column $(1 \times 18 \mathrm{~cm})$ equilibrated with $5 \mathrm{mmol} / 1$ Tris- $\mathrm{HCl}$ buffer, $\mathrm{pH} 8.3$ (DEAE-cellulose) or pH 7.5 (CMcellulose). The columns were eluted with $30 \mathrm{ml}$ of the equilibration buffer followed by a linear $\mathrm{KCl}$ concentration gradient (up to $0.3 \mathrm{~mol} / \mathrm{l}$ ) in the same buffer. Fractions of $5 \mathrm{ml}$ were collected.

\section{Immunological procedures}

We used a rabbit antiserum against homogenous arginase from human liver, which was the $A_{1}$ form of arginase according to Porembska's terminology (11). The antiserum was prepared and tested as recently described (12).
Titration of arginase with antibodies was performed in mixtures containing the enzyme preparation (0.1-0.3 unit), $\mathrm{MnCl}_{2}$ in a final concentration of $5 \mathrm{mmol} / \mathrm{l}$, and appropriate dilution of the antiserum in increasing amounts $(0-50 \mu \mathrm{l})$. The samples were adjusted to a final volume of $1 \mathrm{ml}$ with $5 \mathrm{mmol} / \mathrm{l}$ Tris$\mathrm{HCl}$ buffer, $\mathrm{pH}$ 7.5. Control samples, instead of antiserum, contained normal rabbit serum in appropriate amounts. The mixtures were incubated at $37^{\circ} \mathrm{C}$ for $30 \mathrm{~min}$ and then at $4^{\circ} \mathrm{C}$ for 18 hours to aggregate the enzyme-antibody complexes. They were then removed by centrifugation at $25000 \mathrm{~g}$ for $30 \mathrm{~min}$, and the residual arginase activity determined in the supernatant. The residual fraction of arginase activity remaining in the supernatant was expressed in relation to the units of arginase added, which were taken as 1.00. The amounts of the antiserum added were expressed per 1 unit of arginase.

\section{Results}

\section{Bacterial contamination}

The presence of the physiological bacterial flora has no influence on arginase activity in saliva. Specimens of saliva after centrifugation and incubation with 2mercaptoethanol at $0^{\circ} \mathrm{C}$ for 2 hours were filtered through the Millipor bacteriological filter type HA $0.45 \mu \mathrm{m}$. No difference were found in arginase activity before and after filtration.

\section{Enzyme characteristics}

\section{Manganese dependence}

Incubation at $55^{\circ} \mathrm{C}$ for 20 min with a $\mathrm{Mn}^{2+}$-concentration of $5 \mathrm{mmol} / \mathrm{l}$ fully activates salivary arginase (fig. $1 \mathrm{a} / \mathrm{b}$ ). High concentrations inhibit the enzyme. In the presence of the same $\mathrm{Mn}^{2+}$ concentration, the average activity after preincubation is 3 times higher than without preincubation (tab. 1).

\section{pH optimum}

The $\mathrm{pH}$ optimum of the activated enzyme in carbonate buffer was $9.6-9.8$ (fig. 2).

\section{Michaelis constant}

The $K_{\mathrm{m}}$ of the activated salivary arginase for arginine at $\mathrm{pH} 9.8$ was $4.2 \pm 0.7 \mathrm{mmol} / \mathrm{l}$ (fig. 3).

\section{Stability on storage}

Salivary arginase was more stable on storage at $0^{\circ} \mathrm{C}$ than at $-10^{\circ} \mathrm{C}$. At $0{ }^{\circ} \mathrm{C}$ no detectable loss of the enzyme activity was observed for at least two days. After one week the enzyme still retained $80 \%$ of its initial activity. At $-10^{\circ} \mathrm{C}$ the enzyme was extremely - labile, losing a fraction of about 0.50 of its initial activity in one day (fig. 4). : : 


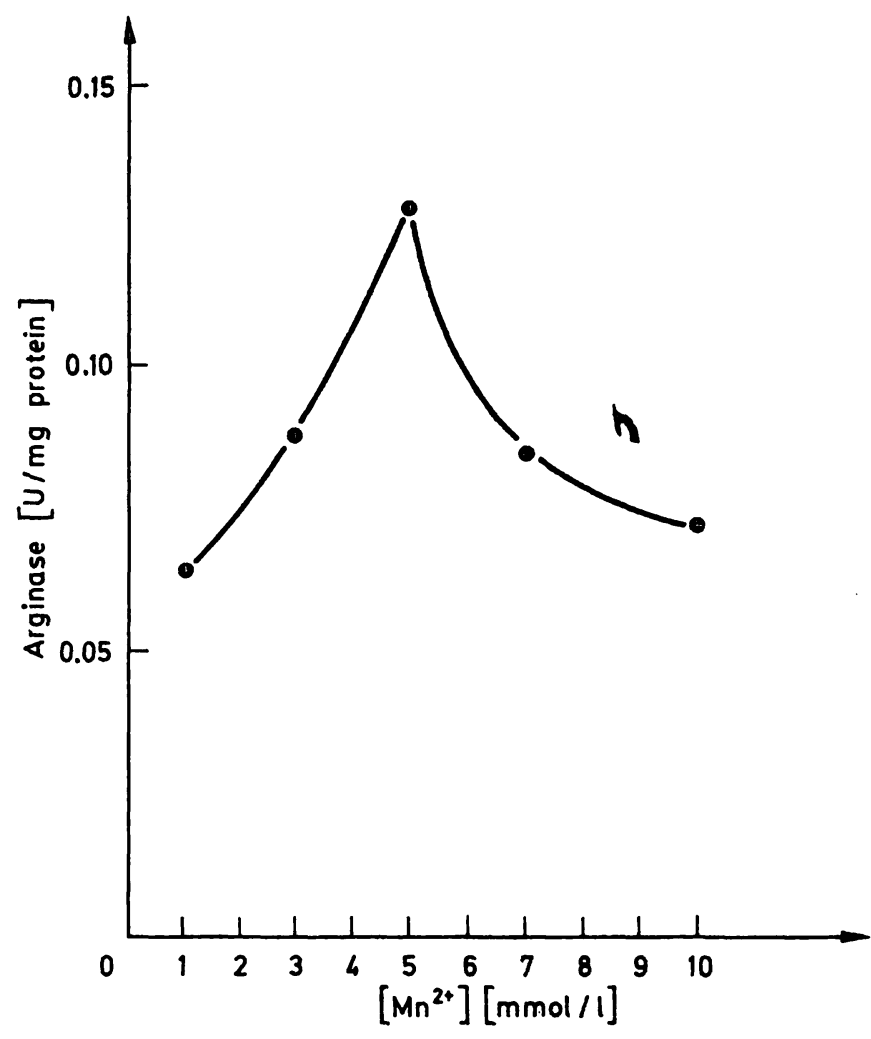

Fig. 1a. Effect of manganese concentration on arginase catalytic activity in saliva.

Saliva was preincubated at $55^{\circ} \mathrm{C}$ for $20 \mathrm{~min}$ with $\mathrm{MnCl}_{2}$ at final concentrations of $1-10 \mathrm{mmol} / \mathrm{l}$.

Tab. 1. Arginase catalytic activity in saliva of normal adults and children ( $\bar{x} \pm 1 S D$, range values in brackets).

\begin{tabular}{lccc}
\hline Donors & $\mathrm{n}$ & \multicolumn{2}{c}{ Arginase, $\mathrm{U} / \mathrm{mg}$ protein } \\
& & nonactivated & $\mathrm{Mn}^{2+}$-activated \\
\hline Adults & 60 & $0.06 \pm 0.04$ & $0.17 \pm 0.11$ \\
& & $(0.01-0.230)$ & $(0.02-0.51)$ \\
Children & 8 & $0.06 \pm 0.03$ & $0.16 \pm 0.06$ \\
& & $(0.03 \pm 0.11)$ & $(0.09-0.28)$ \\
\hline
\end{tabular}

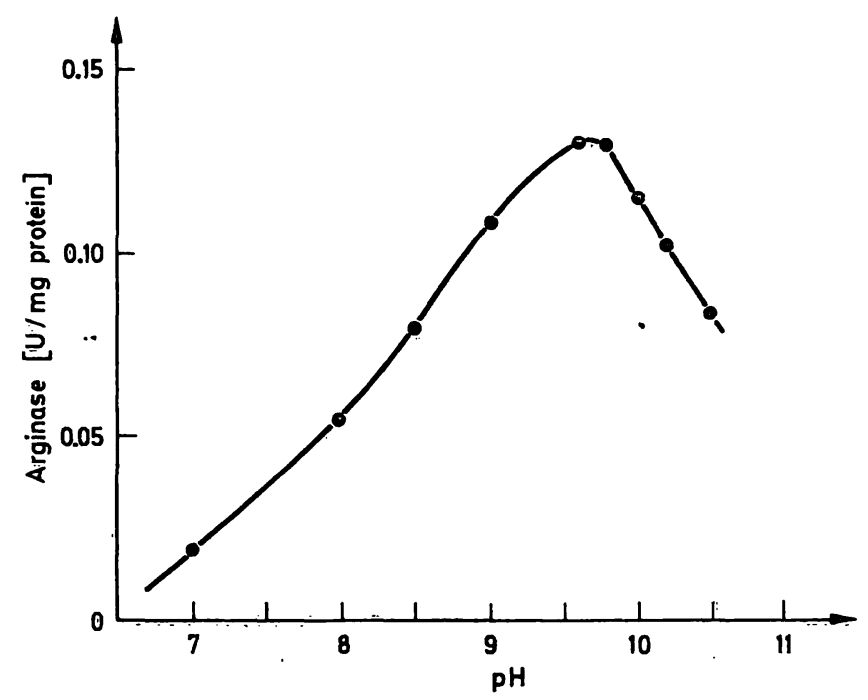

Fig. 2. Relation between $\mathrm{pH}$ and catalytic activity of salivary arginase.

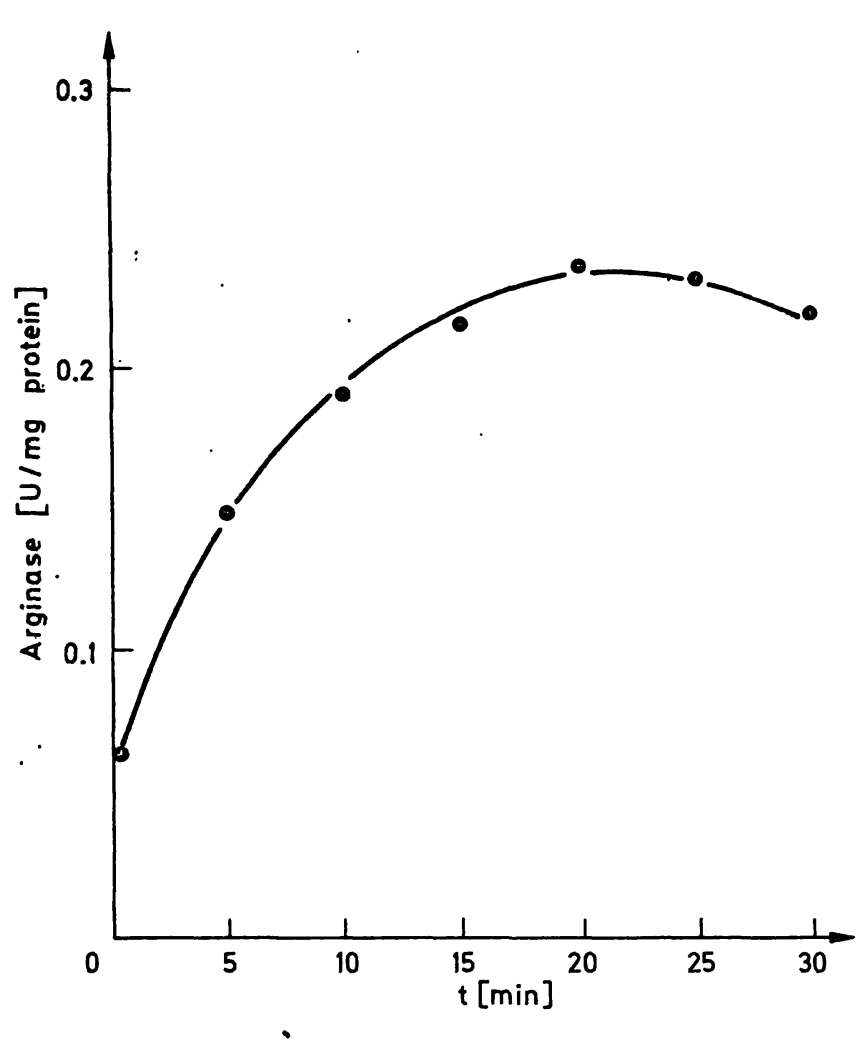

Fig. 1b. Time dependence of activation with $\mathrm{Mn}^{2+}$-ions. Saliva was preincubated for $5-30 \mathrm{~min}$ at $55^{\circ} \mathrm{C}$ with $\mathrm{MnCl}_{2}$ at a final concentration of $5 \mathrm{mmol} / \mathrm{l}$.

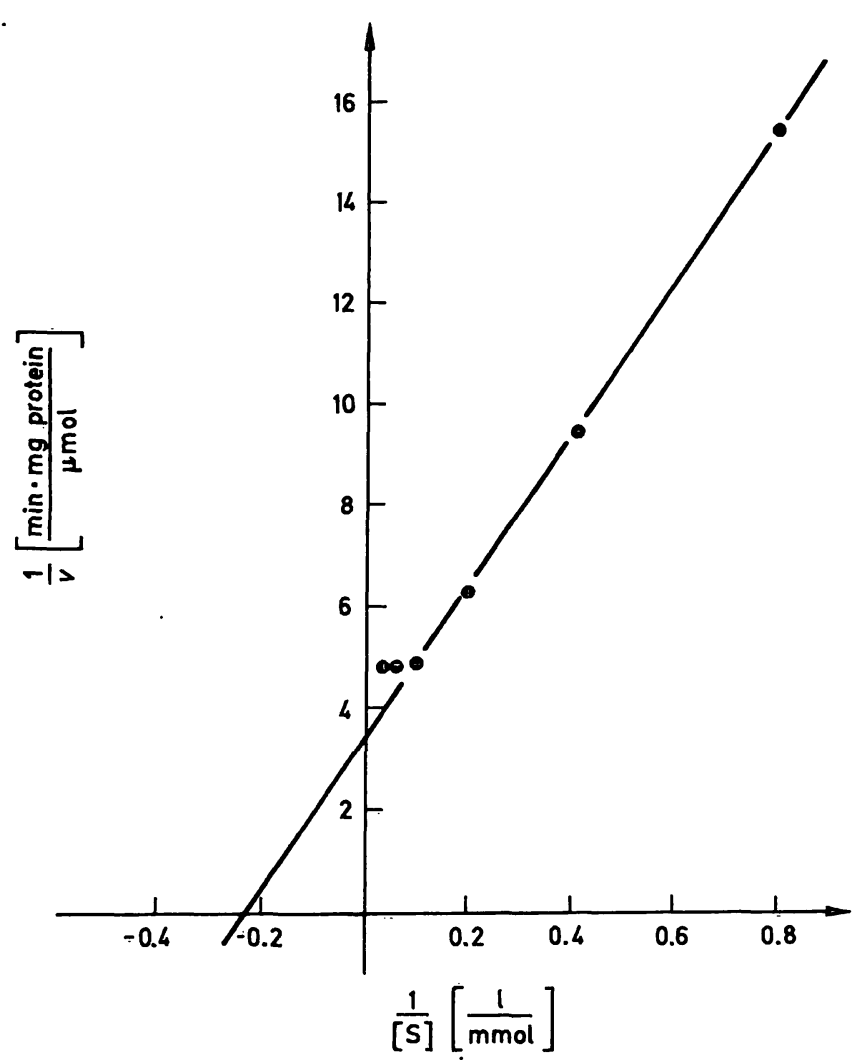

Fig. 3. Lineweaver-Burk plot, substrate $L$-arginine.

The activity was measured in mixtures containing increasing concentrations of arginine $(1-40 \mathrm{mmol} / \mathrm{l})$, $\mathrm{Mn}^{2+}$-activated enzyme and carbonate buffer, $\mathrm{pH} 9.8$. The velocity $(v)$ is given in $\mu \mathrm{mol} / \mathrm{min} \cdot \mathrm{mg}$ protein for ornithine as the product. 


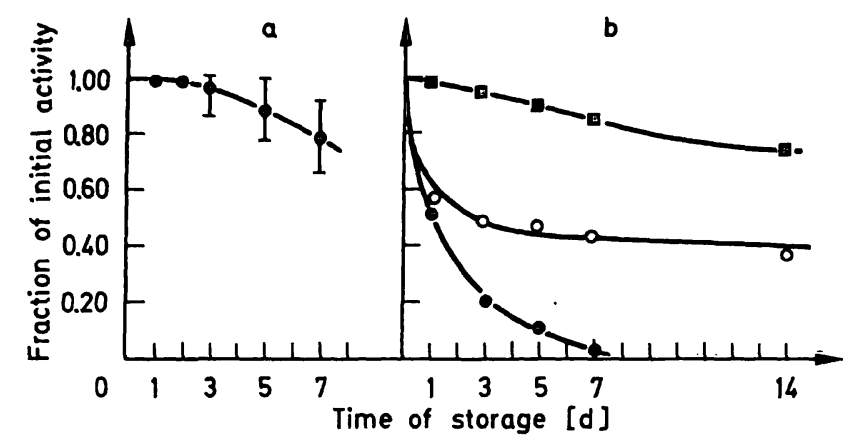

Fig. 4. Stability of salivary arginase on storage at $0^{\circ} \mathrm{C}(\mathrm{a})$ (mean and range of 20 specimens), and $-10^{\circ} \mathrm{C} \mathrm{(b)} \cdot(3$ different specimens).

\section{Chromatographic properties}

Ion exchange chromatography on DEAE- and CMcellulose revealed a single cationic form of arginase in human normal saliva (fig. $5 \mathrm{a} / \mathrm{b}$ ). The enzyme was not absorbed on DEAE cellulose at $\mathrm{pH} 8.3$ and was eluted from the column with the equilibrating buffer. On CM-cellulose a single arginase peak was eluted with a $\mathrm{KCl}$ concentration gradient.

\section{Immunological properties}

Antiserum titrations and immunoprecipitations of salivary arginase were carried out with rabbit antiserum against human liver arginase. The antiserum also cross-reacted with arginase in the saliva of argininaemia heterozygotes and in normal human erythrocytes (fig. 6).

\section{Arginase catalytic activity in saliva}

\section{Arginase activity in saliva of normal subjects}

Arginase activity in the saliva of 60 normal adults increased after activation with $\mathrm{Mn}^{2+}$ and amounted to $0.17 \pm 0.11 \mathrm{U} / \mathrm{mg}$ protein. The within assay $\mathrm{CV}$ was $3.8 \%$ for a mean activity of $0.09 \mathrm{U} / \mathrm{mg}$ protein. We found no significant differences in the activities of salivary arginase of normal adults and children. In both age groups the range of the enzyme activity was wide (tab. 1).

To evaluate variations of enzyme activity in the saliva - of the same subjects, arginase was assayed in specimens taken repeatedly during several days from the same person. We found differences up to $7 \times$ the enzyme activity in various samples from the same donor (fig. 7).

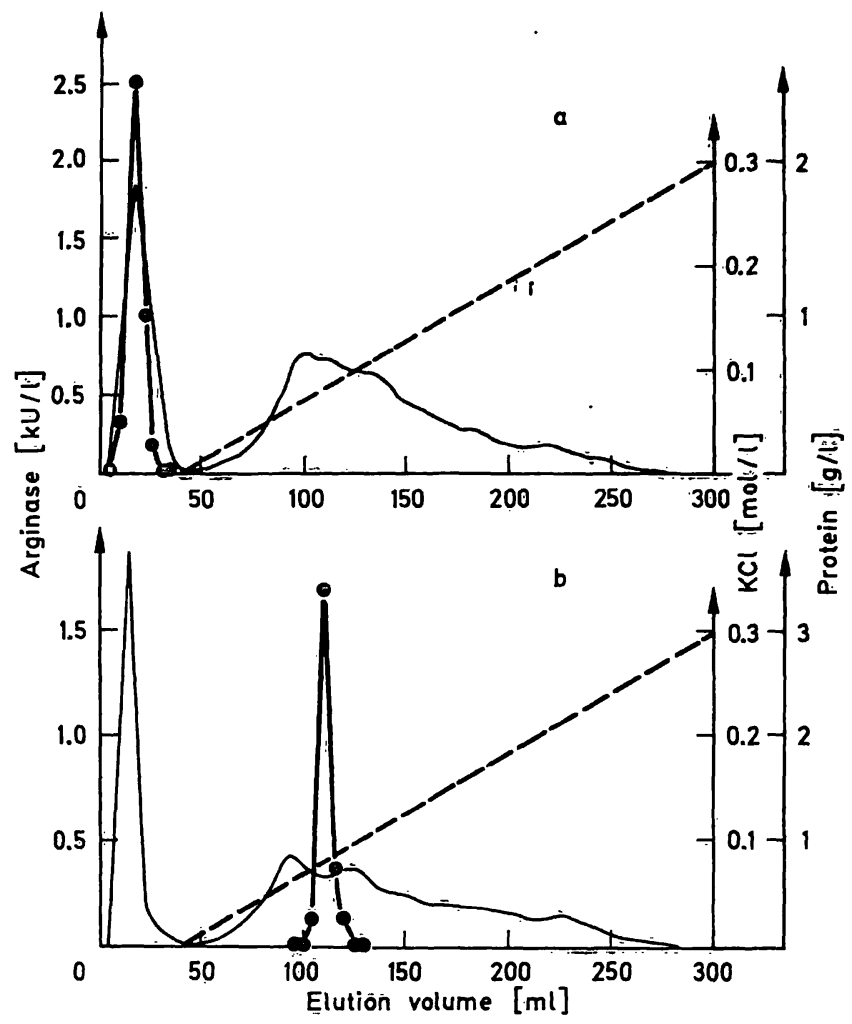

Fig. 5. Chromatography on DEAE-cellulose (a), and CMcellulose (b) of arginase from normal human saliva. $\theta=$ arginase activity, $-\longrightarrow$ protein, $=--=$ $\mathrm{KCl}$ concentration gradient.

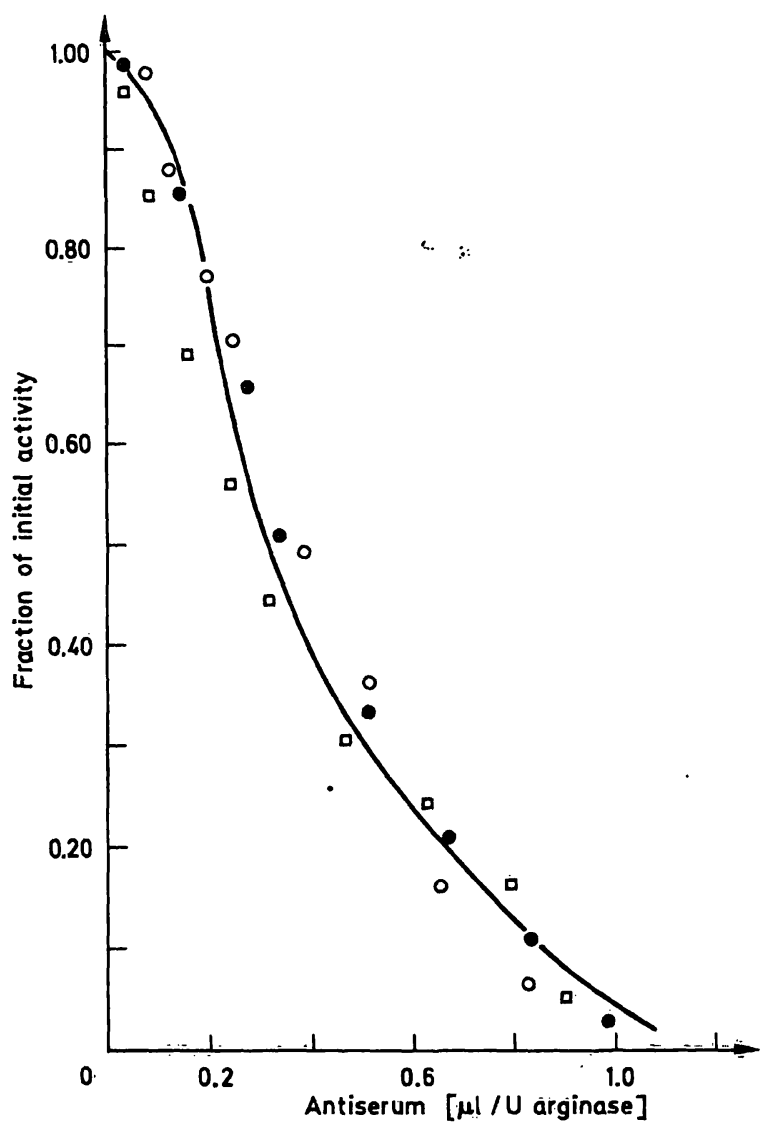

Fig.6. Antiserum titration of arginase from saliva of normal subjects (O), argininaemia heterožzygote $(\square)$, normal human erythrocytes $(O)$. 


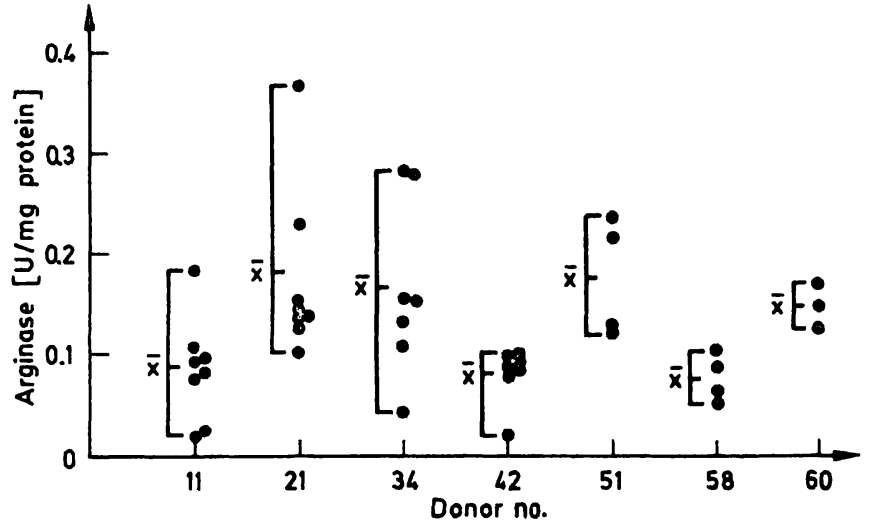

Fig. 7. Variation of arginase activity in saliva of the same subject ( $\overline{\mathrm{x}}=$ mean value).

\section{Activity of salivary arginase in argininaemia}

The activity of arginase in the saliva of argininaemia homozygotes was not detected under the assay conditions used for normal saliva. Arginase activity in the saliva of the heterozygous parents and the unaffected daughter was within the range of the control group (tab. 2).

Tab. 2. Catalytic activity of salivary arginase in a family with argininaemia.

\begin{tabular}{lll}
\hline Donor & Genetics & $\begin{array}{l}\mathrm{Mn}^{2+} \text {-activated } \\
\text { arginase } \\
\text { U/mg protein }\end{array}$ \\
\hline Mother & Heterozygotes & 0.08 \\
Father & & 0.07 \\
Healthy daughter & & 0.11 \\
Affected daughters: & Homozygotes & 0.13 \\
W. A., W. M., W.I. & & not detectable \\
\hline
\end{tabular}

\section{Discussion}

Arginase catalyzes the last step of the urea cycle. In humans it is found mainly in the liver; lower catalytic activities have been observed in erythrocytes, leukocytes, platelets, kidney, skeleton and heart muscle, brain, intestines, pancreas, lung, epidermis, placenta, testes, plasma and fibroblasts (9). The metabolic function of extrahepatic arginase is still unclear.

Arginase in saliva originates from the salivary glands. In man it has been demonstrated in the parotid gland (13). Its origin from serum can be excluded, because its activity in serum (14) is up to 400 times lower than in saliva (15). We found a $\mathrm{pH}$ optimum of 9.6 and a maximal manganese activation at $5 \mathrm{mmol} / \mathrm{l}$, compared to $\mathrm{pH} 9.3$ and a $\mathrm{Mn}^{2+}$-concentration of 2 $\mathrm{mmol} / \mathrm{l}$ for the purified liver enzyme (16).
The $K_{\mathrm{m}}$ of $4.2 \pm 0.7 \mathrm{mmol} / 1$ is of similar magnitude to values reported in the literature for the liver enzyme, i.e. $2.5,5.3$ and $7.4 \mathrm{mmol} / \mathrm{l}(16,17,18)$, respectively. Our findings are in agreement with those of Gopalakrishna \& Nagarajan who reported a $\mathrm{Mn}^{2+}$ activation at $2 \mathrm{mmol} / \mathrm{l}$, a $K_{\mathrm{m}}$ of $5 \mathrm{mmol} / \mathrm{l}$, a $\mathrm{pH}$ optimum of $9.7-10.0$ as well as storage instability (15).

Chromatography on DEAE- and CM-cellulose showed one peak, corresponding to the isoenzyme $A_{1}$ according to Porembska, which is the major component of human liver $(0.85)$ and red blood cell $(0.80)$ arginase (11).

Antibodies against human liver arginase $A_{1}$ cross reacted with the salivary enzyme. On the bases of these findings, we postulate that salivary arginase corresponds to the liver type $A_{1}$-isoenzyme. This isoenzyme has been demonstrated by Porembska in the parotid gland tissue (13) and contributes chiefly to the arginase activity of mixed saliva.

Mixed saliva can easily be collected during unstimulated secretion. It has increasingly been used instead of separate collection of saliva for clinical chemical analysis of hormones, drugs and enzymes. Arginase activity in mixed saliva has recently been used as a parameter to evaluate the nutritional status of children (19).

Mixed saliva was also used in our patients because collecting samples from separate glands was impossible in the three mentally retarded children with argininaemia. However, in this case, we have ruled out the possibility of interference from bacterial arginase.

Arginase activity, even with complete activation, is very low in mixed saliva. This may be related to the low activity of arginase observed in the parotid gland (13), which was 400 times lower than in liver tissue and about 6 times lower than in red blood cells.

There wàs a large overlap between argininaemic heterozygotes and normal individuals. The explanation for this remains uncertain. Since the enzyme activity has been referred to the protein concentration, changes in protein content in relation to the salivary flow rate may influence the results. These changes, however, are small under the conditions applied here, and they would be of consequence only for a prolonged and intensive stimulation of the salivary glands (20). Whether arginase secretion is flow-dependent was not examined. In view of the recent observations with salivary amylase this is rather improbable at low basic secretion rates (21). The overlap between normal individuals and heterozygotes may therefore be attributed to biological variations. 
No activity was demonstrated in the saliva of the argininaemia patients. Saliva can therefore be used for rapid enzyme determination. In our opinion the diagnosis of argininaemia, however, must be confirmed by enzymatic determination in red cell preparations and, if possible, in liver tissue.

\section{References}

1. Michels, V. V. \& Beaudet, A. L. (1978) Clin. Genet. 13, $61-67$.

2. Terheggen, H. G., Schwenk, A., Lowenthal, A., Van Sande, M. \& Colombo, J. P. (1969) Lancet II, 748-749.

3. Cederbaum, S. P., Shaw, K. N. F. \& Valente, M. (1977) J. Pediat. 90, 569-573.

4. Snyderman, S. E., Sansaricq, C., Chen, W. J., Norton, P. M. \& Phansalkar, S. V. (1977) J. Pediat. 90, 563-568.

5. Marescau, B., Pintens, J., Lowenthal, A., Terheggen, $H$. G. \& Adriaenssens, K. (1979) J. Clin. Chem. Clin. Biochem. $17,211-217$.

6. Terheggen, H. G., Lowenthal, A., Lavinha, F. \& Colombo, J. P. (1975) Arch. Dis. Childh. 50, 57-62.

7. Snary, D., Allen, A. \& Pain, R. H. (1970) Biochim. Biophys. Res. Comm. 40, 844-851.

8. Chinard, F. P. (1952) J. Biol. Chem. 199, 91-95.

9. Colombo, J. P. \& Konarska, L. (1984) In: Methods of Enzymatic Analysis (Bergmeyer, H. U., ed.) 3rd Edition, Vol. IV, pp. 285-294, Verlag Chemie, Weinheim.

10. Lowry, O. H., Roseborough, A. L., Farr, A. L. \& Randall, . R. J. (1951) J. Biol. Chem. 193, 265-275.
The kinetic, chromatographic and immunological similarities of liver, red blood cell and salivary arginase suggest their genetic identity. Its deficiency in argininaemia provides evidence that although this protein originates from different tissues, it is under the control of the same gene locus.

11. Porembska, $\bar{Z}$. (1973) Enzyme 15, 198-209.

12. Konarska, L., Wiesmann, U., v. Fellenberg, R. \& Colombo, J. P. (1983) Enzyme 29, 44-53.

13. Porembska, Z. \& Kedra, M. (1971) Bull. Acad. Pol. 19, 633-637.

14. Porembska, Z. \& Kedra, M. (1975) Clin. Chim. Acta 60 , $355-361$

15. Gopalakrishna, R. \& Nagarajan, B. (1978) Indian J. Biochem. Biophys. 15, 488-490.

16. Berüter, J., Colombo, J. P., Bachmann, C. (1978) Biochem. J. $175,449-454$.

17. Cobello, J., Basilio, C. \& Prajoux, V. (1961) Biochim. Biophys. Acta 48, 148-152.

18. Nishibe, H. (1973) Physiol. Chem. Physics 5, 453-462.

19. Agarwal, P. D., Agarwal, K. N. \& Agarwal, D. K. (1984) Amer. J. Clin. Nutr. 39, $181-184$.

20. Schöni, M., Kaiser, D., Drack, E. \& Axmacher, U. (1975) Europ. J. Clin. Invest. 5, 153-158.

21. Agarwal, R. P. \& Henkin, R. I.. (1984) Metabolism 33, $797-807$.

Prof. Dr. J. P. Colombo

Chemisches Zentrallabor

Inselspital

CH-3010 Bern 